\title{
Reciprocity in the Civil Economy: a Critical Assessment
}

\author{
María Guadalupe Martino*, Christian Müller*** \\ Institut für Ökonomische Bildung, Westfälische Wilhelms-Universität Münster, Scharnhorststr, 100, 48151 Münster, Germany
}

Received June 02 2017; Accepted July 042017

\begin{abstract}
The civil economy approach is an attempt to reconcile economic market interactions with the normative standards of traditional virtue ethics. We analyze critically some of its main elements with a special focus on the concept of reciprocity, which plays a central role in the whole approach. Its strengths include, among others, virtue orientation, emphasis on happiness rather than utility, and in particular the notion of reciprocity. However, we argue that this concept of reciprocity would on average not be incentive compatible, and from a methodological point of view, the implied hypothesis of a homo reciprocans is not a viable alternative to the standard model of homo oeconomicus. We also consider that the approach is not entirely new, as it shares many characteristics with the social market economy conception.
\end{abstract}

Keywords: Reciprocity • Civil economy $•$ Homo reciprocans $\bullet$ Ordoliberalism $\bullet$ Virtue ethics

\section{Introduction}

The civil economy (CE) approach, as developed by Italian economists Bruni and Zamagni (2007), is an attempt to reconcile economic market interactions with the normative standards of traditional virtue ethics. The authors start from two main observations (Bruni and Zamagni 2007, p.17). First, globalization disempowers the state in its redistributive function. It is therefore not only the government activity that is responsible for redistribution but also the firm interacting in the marketplace, "which now is required to become 'social' in its normal economic activity" (Bruni and Zamagni 2007, p.18).

Second, interpersonal relationships in the economy cannot be reduced just to contractual exchange, as individual dignity and the correspondig rights do not depend on people's abilities to conclude contracts. Consequently, economics must be more than an analysis of contracts and also a theory of a gift exchange.

Although we sympathize very much with the approach in general, in what follows, we provide a critical examination of some basic concepts and central ideas of CE theory. We first give a short overview of the CE approach (Section 2) and emphasize some of its strenghts (Section 3). We then point out some problems associated with the approach. We hereby do not intend to provide a comprehensive critique of CE. Rather, we focus on the concept of reciprocity which we believe that has precedents in the tradition of the social market economy (SME) (Section 4). We consider as problematic the notion of reciprocity as put forward by Bruni and Zamagni, not only with respect to its specific content but also from a methodological perspective (Section 5). The paper ends with some conclusions (Section 6).

\section{The conception of a CE}

Zamagni's and Bruni's CE approach is intended to provide a cultural perspective, which, according to the authors, would "set the basis for a diverse economic 
theory. ${ }^{\text {" }}$ (Bruni and Zamagni 2007, p.14). Their approach has its roots in the Middle Ages and civic humanism of the 15th and 16th centuries and was later revived in the 18th century, particularly in the Neapolitan School led by Antonio Genovesi. ${ }^{2}$ The contemporary version is currently being developed by economists Bruni and Zamagni, who intend to revive the essential values of this tradition, which they describe as "the science of good social being" (p.79), to humanize the economy (Bruni and Zamagni 2007, p.163; Zamagni 2013, p.40). In this sense, they do not intend to design a new model, but to recall what they consider the "original vocation" of the market economy, i.e. oriented toward the common good (Bruni and Zamagni 2016, viii).

The historical tradition of CE has considered economic activity itself as a place of civilization, which is oriented toward the achievement of social well-being (Bruni and Zamagni 2007, p.80) and the common good as dependent on spreading civil virtues throughout the population. The concept of "civil virtue" was defined as "a person's capacity to both discern public interest and act in conformity with it", and these virtues were supposed to be encouraged by various institutions through education and work. (p.86). Related to this idea was the notion of "public faith", which was considered as a precondition for economic development and required to have "a genuine and non-instrumental love for the common good" (p.87).

The central thesis of the modern CE conception is that contemporary social and economic systems only aim at realizing efficiency and redistribution, overlooking the importance of individual ethics, primarily in the form of reciprocity (Bruni and Zamagni 2007, p.19). On the one hand, the market must provide an efficient allocation of all goods and services. The central instrument in that sphere is contractual exchange leading to Paretoefficient results in the marketplace. On the other hand, the task of redistributing individual wealth and incomes is allocated to the government, when the market fails to provide social results that are fair in the sense of distributional justice.

Unlike this standard approach, Bruni and Zamagni (2007, p.20) emphasize that individuals ultimately strive for eudaimonia in the Aristotelian sense, which may be realized by individual reciprocal acts. They borrow the idea of "reciprocity" from the CE tradition, which Genovesi conceived as "the originality of the human being" (Bruni and Zamagni 2007, p.91) and,

1 "Theory" is considered "essentially as a point of view of reality." (Bruni and Zamagni 2007, p.14).

2 Genovesi, A. (2013) Lezioni di commercio o sia di economia civile (1765-76), Mailand, Società Tipografica dei Classici Italiani. therefore, as the governing principle of civil society as well as the fundamental characteristic of market relationships (Bruni and Sugden 2008, p.63). Along the same lines, he considered "public happiness" as constituently relational, meaning that personal happiness implied making others happy, which is closely related to reciprocity (Bruni and Zamagni 2007, p.94). ${ }^{3}$ This relational conception of the human being underlies the whole approach, and it was subsequently taken up by Bruni and Zamagni as one of their central theses in the contemporary perspective.

Within this framework, the abovementioned authors intend to recover the relationship between market and society, as considered by the CE tradition, thus recognizing the essential role that human relationships and reciprocity play in economic activity. Thus, in line with the encyclical letter "Caritas in veritate" (Benedict XVI $2009,36)$, the authors state that:

"Summarily, the central idea in civil economy - and therefore the basis for its practical implications - is that it sees human sociability and reciprocity as core elements of normal economic life. They are neither parallel to, nor prior to or subsequent to, normal economic life. Civil economy shows us that principles other than profit and instrumental exchange can find a place within the economic activity itself." (Bruni and Zamagni 2007, p.17 italics in the original)

This idea can also be appreciated in their discussion of the theories of the so-called "third sector" (Anheier 2014). In this sense, they argue that this sector should be considered as a constitutive part of the economy (Bruni and Zamagni 2007, p.255). This means that its typical organizations, which work according to a "reciprocity" logic and are usually identified with the "third sector", should coexist with traditional for-profit firms in the market. These typical organizations, which are called "civil enterprises" (Bruni and Zamagni 2007, p.181), share some characteristics with the so-called social enterprises (Borzaga and Defourny 2001) and are described as "multi-stakeholder organizations" (Freeman 1984), meaning that they take into account not only the interests of their members (as in the case of social enterprises understood only as cooperatives) but also those on the demand side (Bruni and Zamagni 2007, p.183). The CE perspective states that there should be freedom to choose between different kinds of economic institutions and stresses the idea that "...variety [of types of enterprises] within the market

3 Genovesi (1963): "Autobiografia et lettere", p.449. Quoted in Bruni and Zamagni (2007, p.94). 
is the essential condition for the prosperity of the economic system" (Bruni and Zamagni 2007, p.185).

This coexistence of different kinds of economic organizations in the market could be understood as expressing their conception of harmonizing different regulating principles of the economy, that is, an exchange of equivalents, redistribution, and reciprocity (Bruni and Zamagni 2007, p.22). These principles are usually associated with different spheres, namely the market, the state, and the civil society, respectively. They were previously laid out by Polanyi (2001) and served as a basis for other authors to classify economic systems and explain the corresponding place of the third sector (or social economy) in the economy (Coraggio 2009; Evers and Laville 2004). ${ }^{4}$ However, the CE approach pursues a harmonic participation of the three principles in "the same social system", rather than assigning one principle to each sector (Bruni and Zamagni 2007, p.24). As the authors put it, their conception of the market as oriented toward the common good, and as a place of civilization and sociality which aims at a harmonic participation of those principles, is the "original vocation" of the market. In this sense, the idea behind the CE would be to restore this civilizing function (Bruni and Zamagni 2016, viii).

\section{Major strengths of the CE approach}

Bruni's and Zamagni's conception of a CE is in many respects insightful and original. Among many others, its strengths include its virtue orientation, its emphasis on happiness rather than utility, and, in particular, the notion of reciprocity.

\subsection{Virtue orientation}

By stressing the importance of reciprocity and individual virtues, the authors focus on aspects that have been widely neglected in governance-oriented normative economics. Within the academic mainstream of the discourse on business ethics in Germany, following Homann, there is a tendency to dispense individual morality altogether. As Homann and Blome-Drees (1992, p.35) put it in a much-quoted phrase: "The systematic place of ethics in the economy is the regulatory framework" (our translation; the authors). Therefore, there seems to be no place for individual morality and virtuousness in the well-regulated marketplace. Accordingly, Homann's

4 Other authors, such as Razeto Migliaro (1984), do not refer directly to Polanyi but talk also about three sectors (in this case, market, state, and solidarity economy sector), in quite a similar way. consequentialist approach to moral economics only insufficiently adopts the ideas of the ordoliberal conception of the SME on which it is mainly based. ${ }^{5}$ The conception of a $\mathrm{CE}$, therefore, provides a welcome change of perspectives back to a more Aristotelian approach.

\subsection{Happiness orientation}

This virtue-ethical idea leads to a better understanding of people's ultimate motivations. The authors trace the modern economic standard theory back to the social philosophy of sum-of-utils utilitarianism (Bohnen 1964). As they convincingly argue, happiness is potentially quite a different category from the economists' consequentialist notion of utility (Bruni and Zamagni 2007, p.148), since happiness is often achieved by sacrificing utility. Happiness may better be thought of in terms of Aristotelian eudaimonia rather than mere feelings of individual wellbeing (Lis 2014). As the Second Vatican Council puts it, self-sacrifice may be the way to become happy. Happiness may be an unintended consequence of leading a virtuous life. As paradoxical, as it may seem, happiness may be found by those who do not seek it (Styczen 1979).

Bruni and Zamagni (2007) also emphasize the relational dimension of eudaimonia, which derives from the Aristotelian concept of man as a political creature, as is expressed in the following quotation:

"Surely it is strange, too, to make the supremely happy man a solitary; for no one would choose the whole world on condition of being alone, since man is a political creature and one whose nature is to live with others. Therefore even the happy man lives with others; for he has the things that are by nature good. And plainly it is better to spend his days with friends and good men than with strangers or any chance persons. Therefore the happy man needs friends. (IX,9,1169b)"6

In this sense, Bruni and Zamagni (2007, p.93) consider "public happiness" in the same lines as Genovesi, who conceived happiness as "constituently relational". They also revive some elements from the Italian tradition of social well-being of the 18th century, whose (Aristotelian and Thomist) vision of public happiness was based on a social dimension of well-being (the common good) and a close relationship with the cultivation of the virtues (Bruni and Zamagni 2016, p.90). For this tradition, "the adjective 'public' that normally precedes the word 'happiness' is particularly meaningful,

\footnotetext{
5 See Section 4.

6 Aristotle (1980) Nicomachean Ethics. Oxford: Oxford University Press. Quoted in Bruni (2010).
} 
since it expresses the structurally social nature of happiness: either it is public or it is not" (Bruni and Zamagni 2016, p.88).

\subsection{Reciprocity orientation}

This idea of public happiness is closely linked to the notion of reciprocity, as one of the virtues that may be important for leading a happy life. This concept and its relationship with the economy have been studied from various points of view, that is, from an anthropological perspective $^{7}$ (Mauss 1967; Polanyi 2001; Sahlins 2011) as well as from a microeconomic and experimental one (Fehr and Schmidt, 2005; Kolm, 2005; Sugden, 2004). Having rediscovered the relevance of reciprocity in market interactions is one of the main achievements of CE.

Following Kolm (1994), Bruni and Zamagni (2007, p.167) state that

\footnotetext{
"....reciprocity can be seen as a series of bi-directional transfers, mutually independent yet interconnected nevertheless, among persons who are in a condition of substantial equality (...) Independence implies that every transfer is voluntary (and therefore free) in itself, that there is no prerequisite for the other to enter into action because there is no external obligation capable of influencing the subject's motivation. Its logic is neither conditional (like contract) nor purely unconditional (like philanthropy). The services I render to the other are not a precondition for him/her to act, and yet I cannot reach my objective if the other does not respond."
}

The authors stress three main characteristics, in the abovementioned definition, namely 1) "conditional unconditionality" (Caillé 1998), ${ }^{8}$ 2) bidirectionality of the transfers, which differentiates it from altruism (unidirectional), and 2) transitivity, which means that the reciprocal response does not necessarily have to be directed to the person who prompted it, but possibly toward a third party. The authors associate this characteristic with the generalized reciprocity concept of Hollis (1998).

Other characteristics that are associated with this concept of reciprocity are "freedom" (in comparison to an exchange of equivalents, which entails an obligation of response) and the principle of "proportionality" against the principle of equivalence, which requires a balance between what one gives and what one expects to obtain, but it is not expressed in a definite quantum, because it varies according to other parameters, such

7 A review of the anthropological view is given in Hann (2005).

8 Quoted in Bruni and Zamagni (2007, p.168). as sympathy, benevolence, and fraternity between the subjects involved (Bruni and Zamagni 2007, p.169).

"The essential aspect of the relationship of reciprocity is that the transfers it generates cannot be dissociated from the human relations. In other words, when reciprocity is at work, the objects of the transactions cannot be separated from the acting subjects." (Bruni and Zamagni 2007, p.166)

Thus, reciprocity is considered as the "foundational principle of civil life", and the exchange of equivalents, which is typical of the market (contract), as well as the gift, are both understood as deriving of the principle of reciprocity (Bruni and Zamagni 2007, p.24).

Bruni (2008) develops this idea of contract and gift as derivatives of the principle of reciprocity and presents them as "forms of reciprocity" with different grades of conditionality, namely a) "cooperation without benevolence" (contract), b) "reciprocity of friendship or as philia", and c) "unconditional reciprocity" (gratuitousness, gift).

- The first kind of reciprocity, "cooperation without benevolence", is defined as a relationship without gratuity, where no one has to sacrifice any of his own interest (Bruni 2008, p.27), and is associated with three characteristics, that are typical of contracts, namely, a) conditionality, b) enforceability, and c) exchange of equivalents (p.32). This conception differs from other studies on reciprocity, which consider the exchange as a different principle with other institutional requirements (Kolm 2005, p.397; Polanyi 2001, p.59).

- The second form of reciprocity is associated with the Aristotelian concept of friendship, "philia" (Bruni 2008, p.39) and exhibits the following characteristics: a) equality (this requires long-term equivalence in the content of a series of exchanges, which is not necessarily monetary, and more fundamentally, entails equality between the subjects); b) freedom; c) electiveness (friendship is not transitive and not universalistic); and d) conditionality: this reciprocity is neither purely conditional (contract) nor purely unconditional (gift), recalling Caillés expression, Bruni denominates it as "conditional unconditionality". "It's a reciprocity that takes the first step (...) But the other's response is necessary if the relationship founded upon reciprocity is to last" (Bruni 2008, p.39).

- Bruni (2008, p.46) considers a third form of reciprocity, which he calls "unconditional reciprocity". This is associated with the idea of "gift" (in the sense of providing something without expecting anything in return), but he states that it would still be "reciprocity", because "...the reciprocating behaviour of others does not affect the 'choice' to follow 
this logic of action, but it does affect the 'outcome' of the choice." (Bruni 2008, p.48; italics in the original). The author expresses the different kinds of reciprocity in terms of game theory, which is the usual methodology for analyzing these phenomena from an economic perspective (Axelrod 1984; Sugden 2004; Taylor 1987). He arrives at similar conclusions, but intends to interpret them from another perspective, in his words, in a "more generous" way ${ }^{9}$ (Bruni 2008, p.133), meaning that reciprocal behavior can be inspired by intrinsic motivations (Ryan and Deci 2000), which he associates with the Aristotelian notion of virtue (Bruni 2008, p.136), rather than self-interest, as the standard model assumes (Axelrod 1981).

Bruni and Zamagni's (2007) previously mentioned definition seems to be associated with some characteristics of the second and third kinds of reciprocity defined by Bruni (2008), but does not coincide exactly with either of them. Thus, the "conditional unconditionality" relates it to the second type, but the concept of "transitivity" is explicitly left out of the definition of "philia reciprocity". Transitivity, instead, could be related to the unconditional reciprocity, even though it is not mentioned. He also analyzes the interaction between these different forms of reciprocity and concludes that all the three are necessary for a good society.

Bruni and Zamagni refer to reciprocity as an observed behavior, and as a characteristic of human nature, rather than to reciprocity as a norm. They also stress the freedom of the reciprocity relationships and differentiate this process from the exchange of equivalents, which always requires a response. However, they maintain that reciprocity should be considered as part of normal economic activity, and that in the era of globalization, the firm is "required to become social" (Bruni and Zamagni 2007, p.18), that is, to work according to this principle (e.g., civil enterprises). In this sense, even though the authors seldom make explicit reference to it, reciprocity and all its dimensions can be seen as variants or implications of the biblical Golden Rule (Tob 4:15, Mt 7:12, Lk 6:31) or its universalization as Kant's categorical imperative. ${ }^{10}$

9 He uses this expression in referring to his interpretation of tit-for-tat strategies, which are usually understood as self-interested, but Bruni stressed the unconditionality of the first move and associated it with a cooperative intention.

10 An exception is a footnote in Bruni (2008, p.139): "We could say that while the first two forms [of reciprocity] (especially the first) are expressive of some sort of utilitarian ethics or philosophy, where the criterion for the choice of optimal strategy in a given context is the maximization of utility (or 'happiness', or 'satisfaction', or 'pleasure'), the third form [unconditional] is instead expressive of a deontological ethics, in which the respect of the categorical
As Ythier (2013, p.753) puts it, "The Golden Rule, finally, is the deontological norm that makes benevolent reciprocity a duty."

\section{The normative interpretation of reciprocity}

Although we consider Bruni's and Zamagni's theory important and sympathize with the general thrust of their approach, it seems to be highly debatable, from a methodological point of view, the manner in which normative thinking and positive theory are intertwined in the CE conception. It is thus unclear whether reciprocity is meant to be a norm or an empirical phenomenon.

1. On the one hand, the CE approach as a whole seems to be a normative enterprise. Bruni and Zamagni (2007, p.15) explicitly argue against common "avalutativity" premises of standard economic thinking. The whole CE approach may therefore be read as a postulate that the social and economic order in a given country should achieve efficiency and redistributional justice and that it is a firm's moral obligation to behave according to the reciprocity norm. Thus, firms are morally called upon to behave reciprocally in their everyday activities.

2. On the other hand, the authors seem to expect reciprocity to be widespread (Bruni and Zamagni 2007, p.170). In addition, they provide a detailed critique of the standard economic model of rationality and its predominance in economic thinking. This seems to suggest a positive, behavioral interpretation of the notion of reciprocity.

We consider the implications of both these interpretations in this section and in the following section, beginning with reciprocity as a normative premise.

Within the CE approach, reciprocity is clearly regarded as a moral postulate. One fundamental concept that Bruni and Zamagni draw on from the historical approach is the relationship between ethics and economics, which was expressed in their conception of civil virtues as well as in the explicit orientation of the

imperatives imposes to give up the very idea of calculation and the agent chooses a given strategy on the bases of non-utilitarian tenets." The author discusses other interpretations (e.g., Max Weber, Haregreaves Heap, Elster) as well and concludes that he prefers the interpretation that he outlines in the book. In other words, unconditional reciprocity can be explained in terms of an intrinsic reward associated with the cooperative action (p.51), which he associates with the notion of virtuous action, which also has an intrinsic value (p.136). 
economy to social well-being, reflecting a difference from the standard economic theory. Thus, whereas mainstream economic theory, from a neo-positivist view, considers that ethics and economy belong to different fields and that it is not possible to associate them in any form but by "juxtaposition" (Robbins 1932, p.132), the CE perspective maintains that "scientific reason can serve as a function in the foundation of values, and that values and scientific knowledge are not necessarily mutually opposed" (Bruni and Zamagni 2007, p.15). Therefore, while standard economics considers that economic science is concerned with means but is neutral regarding ends (Robbins 1932, p.23), the CE approach maintains that the economy should be oriented toward the common good (Bruni and Zamagni 2016, viii).

\subsection{Reciprocity as a virtue}

Bruni and Zamagni (2007, p.20) relate their concept of reciprocity to the notion of "fraternity" and differentiate it from the value of solidarity underlying the redistribution task of the state in a very illuminating manner. While solidarity is an impersonal and abstract relationship that can be exercised with people, who one does not even know, fraternity is personal by its very nature. In that sense, solidarity always involves a paternalistic element. In sharp contrast, they argue that fraternity requires reciprocity, which they describe as a personal, anti-paternalistic relationship. While solidarity aims at equality among different people, fraternity, by their definition, is directed to diversity among equals.

However, as convincing as this distinction may be, one wonders whether reciprocity, even in this perspective of fraternity, includes all the virtues that would imply a virtuous life oriented toward happiness, in the sense of the Aristotelian concept of eudaimonia, which is supposed to be one of the guidelines of the approach. Many more individual virtues may come to mind. With respect to Bruni's and Zamagni's third regulating principle of reciprocity, the SME conception is compatible with a whole range of individual virtues that may fulfill the standard of personal integrity, as given in the following sections. In addition, what about courage, truthfulness or tolerance, and other virtues, which may be necessary to achieve eudaimonia in Aristotle's sense? In his insightful book "A Better Way to Think About Business", the virtue ethicist Robert Solomon (1999) spells a complete $\mathrm{ABC}$ of entrepreneurial virtues, from A such as "ability", "ambition", or "autonomy" through Z such as "zeal". Hence, focusing only on gifts, seems to be somewhat reductionist.

\subsection{The reciprocity norm outside the CE tradition}

Bruni and Zamagni convincingly stress that the economy should be governed not only by efficiency and redistributive considerations but also by a normative standard of reciprocity. They present this as something completely new, even claiming that

\begin{abstract}
"The point we want to make here is that our contemporary societies have yet to succeed in giving life to a social order in which all three of these principles are simultaneously integrated. Only two at a time have been put into practice, so far." (Bruni and Zamagni 2007, p.19)
\end{abstract}

This, however, may be true for most competing societal models, but does not apply, for example, to the German conception of a Social Market Economy (SME). Within German economic thinking, the SME label unites a couple of similar conceptions which, since the 1930s, have tried to delineate a "third way" between unrestricted "laissezfaire" capitalism, on the one hand, and the totalitarian conception of a centrally planned economy, on the other hand. Historically, the SME approach goes back to the so-called "Freiburg School" of "ordoliberalism", developed mainly by economists such as Eucken, Röpke, Alexander Rüstow, Karl Paul Hensel, and Leonhard Miksch as well as by jurists such as Franz Böhm and Hans GroßmannDoerth. Their conception of Ordnungspolitik served as a theoretical basis for the economic policy that had gradually been implemented since 1948, most prominently by the German Minister of Economic Affairs, Ludwig Erhard, and his Secretary of State, Alfred Müller-Armack, who coined the programmatic term "Social Market Economy". In addition to the CE conception, in SME, the three principles of efficient resource allocation, redistribution, and individual virtuousness are combined. Moreover, reciprocity is the core element of all dimensions of economic life.

Eucken (2004), the leading figure within the Freiburg School, formulates a set of "constitutive principles" for economic policy to secure the efficiency of market competition and four auxiliary "regulatory principles", so as to correct market results for reasons of distributive justice (for a detailed discussion, see van Suntum et al. 2011). However, the ultimate aim of the regulatory framework for the economy is to ensure that the results of all individual economic market transactions are "universalizable"11 in the sense of the Kant's (1998, p.25) "categorical imperative". Eucken (2004, p.179) looks for an "economic

11 A discussion on the relationship between reciprocity and universalizability is given in Hendry (1999). 
order... in which people are not merely a means to an end, not merely a piece of the apparatus" (our translation) - a formulation that corresponds to Kant's reciprocity principle in its second version.

According to ordoliberal conviction, socialism failed to discern the central role of individual motivation in human action and also overlooked the immense information problems arising in the process of centralized planning and economic allocation. From this point of view, socialism is also to be rejected, because of its conception of man, which degrades the individual as a means of fulfilling the requirements of a plan. Being no more than a small cog in the gear of the government's central plan, man is treated as a will-less thing and thus loses his character as a person: "The apparatus is the end, the man the means" (Eucken 2004, p.177; our translation). However, according to the same reciprocity guideline, an economic policy following a laissez-faire maxim, must also fail. According to Adam Smith's "theorem of the invisible hand", the selfadministered market, as if guided by an "invisible hand", coordinates the multitude of individual interests toward a single overall societal interest. By pursuing their selfish profit-making and utility-maximizing efforts, the economic subjects promote the interest of society without intending to do so and without even knowing it.

What classical libertarians overlook, however, is that sufficient competition over price or quality displays the typical characteristics of a public good to which no one has a rational incentive to contribute. Those who behave fairly in the marketplace while their competitors are engaged in raising their rivals' costs or even destroying them will be the losers in the competitive process. Not only is the protective state threatened by a prisoners' dilemma, as classic liberals convincingly argue (e.g., Buchanan 1975), but also a regulatory framework for the market, which satisfies the categorical imperative, is subject to the same dilemma. Again, the human being is in danger of being treated as a means rather than as an end in itself. According to ordoliberal thinking, the establishment and protection of fair competition have to be a distinctive task of the government.

All undesirable forms of unfair competition (Nichtleistungswettbewerb), which serve only to acquire power over competitors, should be systematically prohibited by the government. Within the given regulatory framework, however, individuals are completely free in their market transactions. The government should essentially confine itself to define and enforce a fair (universalizable) set of rules for the market. It is the ethical norm against which all market results are measured.

Eucken (2004) formulated a set of principles for economic policy in order for it to constitute an economic order guaranteeing universalizable market actions. His efficiency-oriented "constitutive principles" that aim at creating fair competition include the functioning of the price system, the primacy of monetary stability, open markets, private property, freedom of contract, liability, and the continuity of economic policy. If fair competition is once created by the government, it has also to be preserved against interest groups to prevent the underlying prisoner's dilemma from recurring. This is generally regarded as the task of Eucken's regulative principles comprising antitrust policy, income redistribution, and the correction of negative externalities and anomalous labor supply. From a normative standpoint, all these principles may be considered moral norms, which operationalize Kant's principle of universalizability in the economic sphere. (Müller 2013).

The SME, however, is confined to realizing the two regulating principles of the exchange of equivalents and redistribution of wealth, which Bruni and Zamagni (2007, p.21) assign to the usual contemporary conceptions of social order. German ordoliberals also stress the importance of reciprocation in individual exchange. SME theorists generally emphasize that even a wellordered market cannot go without individual morality. Eucken (2004, p.354) argues

"...that the individual is obliged not to act 'egoistically' within the community of the house or business in which he lives or is in personal relations. This is a moral postulate, which always applies in all economic orders" (our translation).

According to ordoliberal thinking, the working of the market mechanism thus presupposes virtues which it cannot bring about itself. As ordoliberal theorist, Röpke (1966, p.186), puts it:

\footnotetext{
"Self-discipline, fairness, chivalry, moderation, common sense, solid moral norms - these are all things people have to bring with them when they enter the marketplace and competition. They are the indispensable supports, both of which prevent degeneration. Family, churches, communities and traditions must equip them... The market economy is a constantly emerging network of more or less short-term contracts. It therefore cannot be maintained if the trust which each contract presupposes cannot rest on a broad basis of moral stability of all parties involved. It therefore depends on a generally satisfactory level of personal integrity." (our translation)
}

Like the theorists of a CE, the founders of the ordoliberal conception of the market also extend their principle of 
reciprocity to the sphere of individual morality. SME, in other words, should, at least in principle, meet the standard of Bruni's and Zamagni's third regulating idea of reciprocity in the marketplace.

\section{The positive interpretation of reciprocity}

\subsection{Reciprocity as an empirical phenomenon}

As to the positive interpretation of the principle, the authors claimed that "reciprocity" in their sense is

\footnotetext{
"... a widespread phenomenon in advanced societies. Not only is it at work in various forms and ways in families, small informal groups, volunteer associations, and communities, etc., but the network of transactions based on reciprocity is present in all typologies of enterprises, from civil enterprises to the various forms of cooperatives in which reciprocity assumes the particular form of mutual help.... every economic activity that has a lasting duration (as firms) cannot be the result of a mere sum of interests, but requires reciprocity. To understand how true this is, think of what the organizations we live in would be like if the practice of gift and reciprocity in both internal and external human relationships were no longer a part of their inner workings" (Bruni and Zamagni 2007, p.170).
}

These statements, however, are hypotheses about reality, which the CE theorists back only sparely with empirical support. In a free state governed by the rule of law, it should be undisputed that individual virtuousness is not to be enforced by government regulation. Rather, virtues have to be self-enforcing if they are to impact on economic interactions. However, acting reciprocally means contributing to a collective good, and it is generally not directly beneficial to the individuals. It may be true that real actors in the marketplace sometimes behave reciprocally. But this does not imply that it will always be the case and that it will be so widespread a behavior that market interactions will take place within a situation of "generalized trust" (Bruni and Zamagni 2007, p.20).

Closely related to that is the authors' statement that "civil enterprises" acting according to the reciprocity norm can coexist with "normal" profit-maximizing firms. Civil enterprises, in their terms, are "multi-stakeholder organizations" that take into account not only the interests of their members but also those of the demand side (Bruni and Zamagni, 2007, p.183). However, since market competition is most appropriately characterized by a prisoner's dilemma structure, civil firms choosing the dominated cooperative strategy will find themselves in the "sucker's" position of the competitive "game". In such a setting, we would expect firms to behave reciprocally, only if doing that pays to them in terms of Olson's (1965) conditions of private provision of public goods or in a prisoners' dilemma supergame where all parties play tit-for-tat strategies (Taylor 1987), turning the equilibrium into one of reciprocal cooperation in all rounds of the infinite game. Herein lies, at least in principle, the very essence of what Bowie (1988) called the "paradox of profits" (for a game theory analysis, see Drummond Nauck 2016).

This, however, is not what Bruni and Zamagni seemed to have in mind, as they argue that "reciprocity in our sense can never be categorized in terms of a repeated game: It is a relationship, and so it cannot be confused with reputation which is an intangible asset" (Bruni and Zamagni 2007, p.170). Given that presupposition, however, it is difficult to understand how reciprocity in the marketplace may be a widespread phenomenon.

\subsection{Reciprocity as a theory of human behavior}

Bruni and Zamagni even seem to have in mind a general theory of behavior as an alternative to standard rational choice theory. They describe the homo oeconomicus "as a social idiot - a person who is so completely absorbed by the rational pursuit of utility that he/ she is oblivious to the fact that in order to reach that aim, he/she must systematically and explicitly manipulate the behaviours and choices of other subjects" (Bruni and Zamagni 2007, p.151).

Bruni and Zamagni also criticize the assumption of "given preferences" (Bruni and Zamagni 2007, p.126), which may be considered one of the main dogmas of rational choice theory. Because economists, according to Stigler and Becker (1977), do not have a theory explaining changes in preferences, they should assume, for methodological reasons, their constancy. Potential changes in behavior should not be explained by a change in preferences, but rather from a change in the constraints (e.g., income). In sharp contrast, Zamagni and Bruni describe preferences as adaptive, in that they vary, depending on the respective contexts (Akerlof and Kranton 2000; Weizsäcker 2015).

The criticism of homo oeconomicus does not stand isolated in the CE approach; it is developed from an analysis of the standard economic theories of the third sector. These argue that if one does not want to explain the emergence of nonprofit companies 
tautologically, one must abandon the anthropological assumption of homo oeconomicus (Bruni and Zamagni 2007, p.143). The authors described the following "dilemma":

\begin{abstract}
"As long as we remain attached to the homo oeconomicus paradigm, we will never find a nontautological explanation for the birth of nonprofit subjects. Of the two alternatives, one holds: either we are dealing with pseudo self-interested subjects with strong prosocial and idealistic motivations and so shatter the anthropological assumption that holds up most of the literature on non-profit organizations. Or we are dealing with hyperrational subjects who pretend to accept the ends of the nonprofit organization in order to bend the situation to their own advantage, and thus we ultimately renounce the attempt to develop a proper economic theory for the NPO." (Bruni and Zamagni 2007, p.143)
\end{abstract}

However, this approach is not entirely convincing; it does not follow from the existence of unselfish Non-profit organizations (NPOs) that the individuals who operate them are not self-interested. Career struggles, envy, misery, the pursuit of promotion, and recognition should also be the case with Caritas or other welfare organizations. An ostensibly nonself-serving organization can be founded on very self-serving motives. Conversely, in a profitmaximizing enterprise, we may find much friendship, altruism, and reciprocity in the sense of the CE approach.

One cannot simply identify a company's collective objective function with the individual objective functions of the people carrying them out. The very essence of morality in personal life, as well as in business, is that it can conflict with selfishness, and this conflict arises only to the extent that moral behavior is costly. As Hoffman (1999, p.53) puts it

\footnotetext{
"... we are ethically required to adopt the moral point of view in all our dealings with other people - and business is no exception. In business, as in all other human endeavours, we must be prepared to pay the costs of ethical behaviour. The costs may sometimes seem high, but that is the risk we take in valuing and preserving our integrity."
}

One cannot overcome this conflict between selfish motivation and morality by simply assuming it away. How, in reality, the gap between selfish profit-maximizing behavior and morally desired reciprocal behavior can be bridged, remains an open question in the conception of the CE.

Moreover, if reciprocity is meant to be a behavioral theory, Bruni's and Zamagni's approach amounts to applying reciprocity to civil enterprises and standard rational choice theory to profit-maximizing firms. From a methodological standpoint, we should, however, feel uneasy about changing the theory of human behavior with respect to the issues to be explained. The explanatory approach then becomes completely ad hoc and thus itself tautological (Tietzel 1985). The abandonment of standard rational choice theory has to be justified differently.

In the CE approach, a type of homo reciprocans takes the place of homo oeconomicus. Bruni and Zamagni(2007, p.170)emphasize that reciprocity does not mean reputation in a repeated game in the sense of Fehr and Schmidt (2005), Falk (2003), Falk and Fischbacher (2006), and others, because it is a relationship (in a one-shot game?). However, this would not only not resolve the dilemma described above, but what is more, another methodological dilemma may arise.

Admittedly, the homo oeconomicus model is unrealistic and even false. We surely hope that people in reality will decide according to a moral standard of reciprocation and thus behave as homines reciprocantes. However, as long as we do not have a general theory describing in which situations people act reciprocally, according to which of the abovementioned types of reciprocity and to what extent inter-individual predictions as to which alternative (or class of alternatives) an individual will choose, will not be possible. This is the same methodological problem as in Smith's theory of moral sentiments that described an intra-individual conflict between sympathy and egoism; Smith's behavioral assumptions did not enable predicting the concrete action to be chosen. Such an approach may appear more realistic than standard homo oeconomicus theory, but in fact loses its empirical content and its predictive power. In extreme cases, such an approach does not "prohibit" anything, and it becomes tautological.

However, the standard concept of rationality does not face this problem. On the contrary, the maximization assumption and the assumptions about the same situational perception standardize or "objectify" the decision situation, so that for each individual agent, there is a single and identical solution for all. As Pareto put it famously: L'indivdu peut disparaittre!. Using those premises, one does not have to explain the behavior of different persons; the analysis of a standard individual suffices (Tietzel 1985, p.92).

In addition, herein lies the methodological dilemma that economists have to face. By proceeding from standard rationality to a more elaborate concept of rationality such as reciprocal behavior, one exchanges not only less empirical content for more realistic assumptions 
but also a lower "manageability" of the analysis and the loss of the uniqueness of the solution (Tietzel 1985, p.92). Implications derived from a standard rationality model are highly falsifiable and, in particular cases, may be empirically false.

On the other hand, the alternatives to homo oeconomicus such as homo reciprocans are, in a sense, more realistic. But their implications are only true in the logical sense (a priori), and hence they say nothing about the reality of life. Not only the predictability of these approaches is limited but also nothing can be derived from them at all. The implications of these approaches are not synthetic but take the form of analytical statements, for example, according to the scheme: "From a set of two alternatives A or B, the individual chooses A or B", depending on whether he or she decides selfishly or reciprocally.

Facing the choice between these two methodological "evils", we preferred to explain reality on average, rather than to say nothing about it at all. We therefore have to live with the fact that our explanations, using Hayek's (1967) expression, can never be more than "explanations of the principle", as opposed to "explanations of the detail." As economists, we can only expect to give "idealized explanations" of real phenomena that may sometimes violate the condition of empirical truth of the explanatory argument (Hempel and Oppenheim 1948), because the factors on which a state of affairs to be explained is dependent are too complex or even unknown (Tietzel 1985, p.111, 1986). Idealized explanations are always only sufficient conditions to deduct logically an explanandum statement. But since the adequacy condition that all statements used in the explanation should be true is violated, the explanatory argument is not necessary to derive the implication. Rather, it could be inferred from a multitude of quite different and equally conceivable explanations.

Accepting idealized explanatory arguments in economics does not mean favoring instrumentalism in the sense of Friedman (1953, see also Meyer 2002, p.63), according to which false laws are to be used for explanations, as long as this leads to acceptable results in a sufficiently large number of applications. Since true conclusions can even be inferred from an argument using only false statements, ${ }^{12}$ the falsity of the assumptions (here, of the rationality hypothesis) would be acceptable according to Friedman.

The problem with this position, however, is that a falsification, which is a precondition for scientific

\footnotetext{
12 From the false statements, "Villa Vigoni is located in Germany." and "Germany is located in Italy." the true conclusion follows logically that Villa Vigoni is located in Italy.
}

progress (Popper 1969, p. 113), requires the conclusions as well as the premises to be true. To explain the occurrence of a singular event, therefore, consciously using false premises is only acceptable if this leads first to explanations in a sufficient number of applications, and second, given that it is intended to be a provisional heuristic method (Tietzel 1986, p.320).

\section{Conclusion}

Bruni's and Zamagni's claim is ambitious; by revitalizing the traditional conception of a CE they aim at nothing less than a "new reading of the entire economic reality" (Bruni and Zamagni 2007, p.14). The CE approach is meant to provide a new "cultural perspective from which we may interpret the entire economic discourse" (Bruni and Zamagni 2007, p.14).

As we have argued in this paper, some questions remain open in the CE approach. For example, despite its explicit claims, it is not clear how the CE approach could resolve the conflict between the moral obligation of reciprocal behavior and individual self-interest. In addition, the implied hypothesis of a homo reciprocans is by no means a viable alternative to the standard model of homo oeconomicus, from a methodological point of view.

On the other hand, the ideas developed in the framework of the CE approach are not completely new, but rather complementary to many insights provided by the SME approach. CE and SME seem to only illuminate the two sides of the same coin:

- $\quad \mathrm{CE}$, on the one hand, by introducing its norm of reciprocity, may be seen as providing a more concrete notion of what individual moral behavior within the regulatory framework of the economy may be all about. It demonstrates how individuals can, by reciprocating between each other and giving gifts, attain happiness even in the marketplace. Accordingly, SME can learn from CE.

- Conversely, the theory of SME emphasizes the important aspect that fair market results do not simply arise by themselves, because they are threatened by a prisoner's dilemma incentive structure. Thus, fair market competition will not arise on its own, but rather has to be created by the government. The important lesson CE can learn from SME theory is that the institutional framework really matters.

CE and SME not only overlap but also offer partly complementary perspectives on the economy and the society. If, and to what extent, it may be a task of government to implement individual reciprocal behavior, remains an open question in both approaches. 
Akerlof G.A., Kranton R.E., Economics and identity, Q J Econ, 105, 715-753, 2000.

Anheier H.K., Nonprofit organizations: theory, management, policy, 2nd ed., Routledge, London, 2014.

Axelrod R., The emergence of cooperation among egoists, Am Political Sci Rev, 75 (2), 306, 1981.

Axelrod R., The evolution of cooperation, Basic Books Inc. Publishers, New York, 1984.

Benedict XVI, Charity in truth: caritas in veritate: encyclical letter, Ignatius Press, San Francisco, 2009.

Bohnen A., Die utilitaristische Ethik als Grundlage der modernen Wohlfahrtsökonomik, Schwartz, Göttingen, 1964.

Borzaga C., Defourny J. (Eds.), The emergence of social enterprise. Routledge studies in the management of voluntary and non-profit organizations, Routledge, London, 2001.

Bowie N.E., The paradox of profit, In: Wright N.D. (Ed.), Papers on the ethics of administration, Brigham Young University, New York, 97-120, 1988.

Bruni L., Reciprocity, altruism and the civil society: in praise of heterogeneity. Routledge advances in game theory, 4th ed., Routledge, London, 2008.

Bruni L., The happiness of sociality. Economics and eudaimonia: a necessary encounter, Ration Soc, 22 (4), 383-406, 2010.

Bruni L., Sugden R., Fraternity: why the market need not be a morally free zone, Econ Phil, 24 (1), 35, 2008.

Bruni L., Zamagni S., Civil economy: efficiency, equity, public happiness, Front Bus Ethics, 2, Peter Lang, Bern, 2007.

Bruni L., Zamagni S., Civil economy: another idea of the market, Agenda Publishing Limited, Newcastle upon Tyne, 2016.

Buchanan J.M., The limits of liberty: between anarchy and leviathan. Chicago, 1975.

Caillé A., II terzo paradigma: Antropologia filosofica del dono [Le tiers paradigme], Saggi, Bollati Borlinghieri, Torino, 1998.

Coraggio J.L., Anexo: sobre el concepto de principios de integración, In: Coraggio J.L. (Ed.), Qué es lo económico? Materiales para un debate necesario contra el fatalismo, CICCUS, Buenos Aires, 16166, 2009.

Drummond Nauck J., Das Gewinnparadox in der Unternehmensethik: Eine spiel-theoretische Analyse, Z Marktwirtsch Ethik, 4 (1), 43-60, 2016.

Eucken W., Grundsätze der Wirtschaftspolitik, Mohr Siebeck, Tübingen, 2004.
Evers A., Laville J.L., Defining the third sector in Europe, In: Evers A., Laville J.L. (Eds.), In the third sector in Europe, globalization and welfare, Edward Elgar, Cheltenham, 2004.

Falk A., Homo Oeconomicus versus Homo Reciprocans: Ansatze fur ein neues Wirtschaftspolitisches Leitbild?, Perspekt Wirtschaftspolitik, 4 (1), 141 172, 2003.

Falk A., Fischbacher U., A theory of reciprocity, Games Econ Behav, 54 (2), 293-315, 2006.

Fehr E., Schmidt K.M., Chapter 8 - the economics of fairness, reciprocity and altruism - experimental evidence and new theories, In: Kolm S., Mercier Ythier J. (Eds.), Handbook of the economics of giving, altruism and reciprocity, Elsevier, Amsterdam, London, 615-691, 2005.

Freeman E.R., Strategic management: a stakeholder approach, Pitman series in business and public policy, Pitman, Boston, 1984.

Friedman M., The methodology of positive economics, In: Milton F. (Ed.), Positive economics, The University of Chicago Press, Chicago, 3-43, 1953.

Genovesi, A., Lezioni di economia civile. Francesca Dal Degan (Ed.). Vita e Pensiero, Milano, 2013.

Hann C., Chapter 4 - the gift and reciprocity: perspectives from economic anthropology, In: Kolm S., Ythier J.M. (Eds.), Handbook of the economics of giving, altruism and reciprocity, Elsevier, Amsterdam, London, 207-223, 2005.

Hayek F.A.V., Degrees of explanation, In: Hayek F.A.V. (Ed.), Studies in philosophy, politics, and economics, Routledge \& Kegan Paul, London, 3-21, 1967.

Hempel C.G., Oppenheim P., Studies in the logic of explanation, Philos Sci, 15 (2), 135-175, 1948.

Hendry J., Universalizability and reciprocity in international business ethics, Bus Ethics Q, 9 (3), 405-420, 1999.

Hoffman M., A blueprint for corporate ethical development, In: Ulrich P. (Ed.), Unternehmensethik in der Praxis: Impulse aus den USA, Deutschland und der Schweiz, St. Galler Beiträge zur Wirtschaftsethik, No. 19. Haupt, Bern, 49-62, 1999.

Hollis M., Trust within reason. Cambridge University Press, Cambridge, New York, 1998.

Homann K., Blome-Drees F., Wirtschafts- und Unternehmensethik, Vandenhoeck \& Ruprecht, Göttingen, 1992.

Kant I., Groundwork of the metaphysics of morals. Translated Gregor M.J. (Ed.), Cambridge texts in 
the history of philosophy, Cambridge University Press, Cambridge, 1998.

Kolm S.C., The theory of reciprocity and of the choice of economic systems: an introduction, Investig Econ, 18 (1), 67-95, 1994.

Kolm S.C., Chapter 6 reciprocity: its scope, rationales, and consequences, In: Kolm S.C., Ythier J.M. (Eds.), The economics of reciprocity, giving and altruism, Elsevier, Amsterdam, London, 371-541, 2005.

Lis J., Nutzen oder Glück: Möglichkeiten und Grenzen einer deontologisch-theoretischen Fundierung der economics of happiness, Schriften zu Ordnungsfragen der Wirtschaft, Band 101, Lucius \& Lucius, Stuttgart, 2014.

Mauss M., The gift: forms and functions of exchange in archaic societies, Norton, New York, 1967.

Meyer W., Grundlagen des ökonomischen Denkens, Albert H. (Ed.), Mohr Siebeck, Tübingen, 2002.

Müller C., Die Soziale Marktwirtschaft Als Wirtschaftlische Konzeption, In: Krylov A.N. (Ed.), Corporate social responsibility: Wirtschaftsmodelle - Moral - Erfolg Nachhaltigkeit, West-Ost-Verlag, Berlin, 41-64, 2013.

Olson M., The logic of collective action, Cambridge, 1965.

Polanyi K., The great transformation: the political and economic origins of our time, 2, Beacon Paperback, Boston, 2001.

Popper K.R., Conjectures and refutations, Henley, London, 1969.

Razeto Migliaro L., Fundamentos de una teoría económica comprensiva. Economía de solidaridad y mercado democrático 3 , Academia de Humanismo Cristiano, Programa de Economía del Trabajo, Santiago, 1984.

Robbins L.R., An essay on the nature \& significance of economic science, Macmillan \& co. limited, London, 1932.

Röpke W., Jenseits von Angebot und Nachfrage, 4, Erlenbach-Zürich, Stuttgart, 1966.
Ryan R.M., Deci E.L., Intrinsic and extrinsic motivations: classic definitions and new directions, Contemp Educ Psychol, 25 (1), 54-67, 2000.

Sahlins M.D., Stone age economics, Transaction Publishers, New Brunswick, NJ, 2011.

Solomon R.C., A better way to think about business: how personal integrity leads to corporate success, Oxford University Press, New York, Oxford, 1999.

Stigler G.J., Becker G.S., De Gustibus Non Est Disputandum, Am Econ Rev, 67 (2), 76-90, 1977.

Styczen T., Karol Wojtyla - Philosoph der Freiheit im Dienst der Liebe, In: Wojtyla K. (Ed.), Erziehung zur Liebe, Stuttgart, 1979.

Sugden R., The economics of rights, co-operation, and welfare, 2nd ed., Palgrave Macmillan, Basingstoke, 2004.

Taylor M., The possibility of cooperation, [Rev. ed.], Studies in rationality and social change, Cambridge University Press, Cambridge, 1987.

Tietzel M., Wirtschaftstheorie und Unwissen: Überlegungen zur Wirtschaftstheorie jenseits von Risiko und Unsicherheit, J. C. B. Mohr, Tübingen, 1985.

Tietzel M., Idealisierte Erklärungen, Z Allg Wiss, 17 (2), 315-321, 1986.

van Suntum, U., Böhm, T., Oelgemöller, J., Ilgmann, C., Walter Eucken's principles of economic policy today, CAWM Discussion Paper, 49, University of Münster, Münster, 2011.

Weizsäcker C.C.V., Adaptive Präferenzen und die Legitimierung dezentraler Entscheidungsstrukturen, In: Müller C., Otter N. (Eds.), Behavioral economics und Wirtschaftspolitik, Schriften zu Ordnungsfragen der Wirtschaft, 100, Lucius \& Lucius, Stuttgart, 67-98, 2015.

Ythier J.M., Distributive justice and benevolence: the welfare state as practical, distributive, liberal social contract, Rev Écon Polit, 123 (5), 737-761, 2013.

Zamagni S. (Ed.), Por una economía del bien común, Ciudad Nueva, Buenos Aires, 2013. 